\title{
TRUST, CELL PHONES, SOCIAL NETWORKS AND AGRICULTURAL ENTREPRENEURSHIP IN EAST AFRICA: A DYNAMIC INTERDEPENDENCE
}

\author{
Mehta $\mathbf{K}^{{ }^{*}}$, Maretzki $\mathrm{A}^{2}$ and L Semali ${ }^{3}$
}

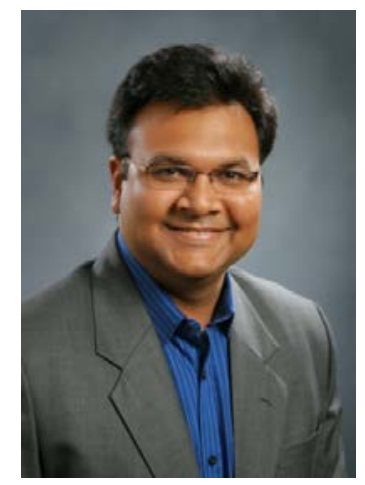

Khanjan Mehta

*Corresponding Author Email: khanjan@engr.psu.edu

${ }^{1}$ Humanitarian Engineering and Social Entrepreneurship (HESE) Program, College of Engineering, The Pennsylvania State University, University Park, PA 16802.

${ }^{2}$ Department of Food Science, College of Agricultural Sciences, The Pennsylvania State University, University Park, PA 16802.

${ }^{3}$ College of Education, The Pennsylvania State University, University Park, PA 16802. 


\section{ABSTRACT}

African entrepreneurs operate within homogenous, tightly knit social networks of trusted individuals. 'Who you know' networks can provide these entrepreneurs with significant advantages in social, economic or political situations. However, the challenge of expanding beyond such networks to access new knowledge, skills and resources can be met only by establishing relationships with individuals outside their existing sphere of trust. The widespread adoption of cell phones has radically impacted the social connectedness of agro-entrepreneurs in Africa and deeply affected their social networks and livelihoods. Cell phones help to easily maintain long distance business connections as well as social ties and decrease dependency on local, face-to-face interactions. New weak social ties may be economically beneficial because they can provide access to new resources and create larger networks. The mobile phone enables and accelerates these social network transformations and helps entrepreneurs aggregate and leverage social capital. A symbiotic relationship exists between social and economic capital. Social capital is generated through the existence of trust which, in turn, encourages cooperation in the generation of economic capital. The existence of trust can promote the growth of an individual's business network which could, in turn, promote greater economic activity. Trust assumes a very important role in developing communities where there is a significant overlap between people's social and economic networks. This paper defines the crucial role of trust in the complex interdependent relationships among social networks, cell phones and agricultural entrepreneurship. We present a diagram which illustrates that the most compelling opportunities for sustainable value creation and self-determined development in Africa may exist at the intersection of cell phones, social networks and entrepreneurship, with the necessary condition that trust, the glue that holds these elements together, is present. A capstone case-study of a nutribusiness cooperative established in the 1990s suggests the importance of social networks and trust building in an entrepreneurial venture involving rural Kenyan women. This paper provides the context for a companion research paper on the "who you know" social and economic network knowledge systems among rural women agro-entrepreneurs in Northern Tanzania and the role cell phones play within these networks. We use secondary data, including academic publications, UN datasets, business ventures and personal observations to describe the role of trust in the dynamic interdependence among entrepreneurship, social networks and cell phones that is crucial for the establishment of sustainable agricultural business ventures in East Africa.

Key words: social networks, trust, cell phones, entrepreneurship 


\section{INTRODUCTION}

The current agricultural development agenda is being driven by entrepreneurial initiatives undertaken by individuals and cooperative groups in urban and rural communities throughout East Africa. These initiatives involve local entrepreneurs who are enmeshed in social networks that may either support or inhibit their economic and social success. At the micro level, East African entrepreneurs operate within homogenous, tightly knit social networks of trusted individuals. However, the challenge of expanding beyond such networks to access new knowledge, skills and resources can be met only by establishing relationships with individuals outside their existing sphere of trust. The process of expanding social networks depends upon the establishment of trust that functions as glue in the building of productive business and social relationships. The rapid emergence of cell phone technologies in East Africa creates an opportunity for entrepreneurs to selectively expand their social networks to include business and social contacts they judge to be worthy of their trust and able to meet their needs as entrepreneurs.

The growing popularity and use of cellphones, to enhance accessibility to, and improve the function of, supply and value networks, requires further examination. This paper attempts to illustrate the critical nature of trust in the complex interdependent relationships among social networks, cell phones and agricultural entrepreneurship. The first section discusses the basic tenets of social networks, cell phones, and agricultural entrepreneurship and builds on previous work by including a discussion on concept of trust [1]. The second section presents a model that illustrates the role of trust as the "glue" that connects social networks, entrepreneurship and cell phones. The role of trust in connecting these three elements is discussed in this section. The paper culminates with a case-study illustrating how trust dynamics related to cell phones andsocial networks might have supported the sustainability and scalability of women's nutribusiness co-operatives in Kenya. This paper provides the theoretical basis for an accompanying paper that discusses a research initiative conducted by our team to study the social networks of women agro-entrepreneurs in Tanzania and the role cell phones play within these networks. The objective of this study was to identify opportunities for developing innovative cell phone-based applications that link small-scale farmers and other entrepreneurs to markets, thus enabling these entrepreneurs to utilize, strengthen and expand their social and economic networks. A complementary goal was to identify the characteristics of women who are likely to successfully champion new entrepreneurial ventures.

\section{Social Networks}

A social network is defined as all the persons (nodes) to whom an individual is linked through social ties thereby creating relationships that serve the needs of the individuals involved[2]. Social capital can be defined as the value created by personal connections that are facilitated by social networks. The term 'social network' as used throughout this paper, includes social relationships, economic relationships, and other forms of relationships between actors or agents. A distinction between economic and social networks is not made because there is a very significant overlap between them in Africa and in most communities in the developing world. The individual, the set of

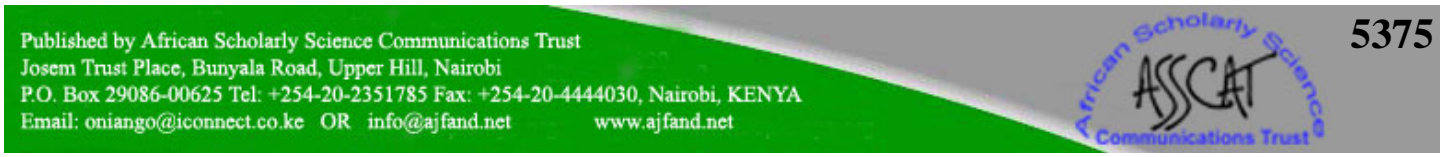


nodes that the individual has ties with, and all ties among those nodes collectively form an ego network. In this paper, social networks refer to ego networks where the specific nodes of interest are small-scale agro-entrepreneurs and their ties or relationships to each other and to individuals and organizations related to their area of economic activity.

Social contacts may be related to the entrepreneur in several types of relationships or interactions. Network analysis can be used to understand the roles of individuals (egos) within a social group [3]. In single-stranded relations, each person performs only one activity with the entrepreneur and is related to that person through only one type of relationship. Multiplex ties, in contrast, have several relationship roles and the same individual may play numerous roles in the entrepreneur's support group. In Africa, social and economic networks are inter-connected and hence multi-stranded networks are prevalent [3]. Also, "who you know" network knowledge systems are prevalent and may extend beyond an individual's immediate social network to a larger collective network that couldprovide a useful advantage in social, political or economic situations[4].

\section{Entrepreneurship}

Entrepreneurship is the engine and driving force of an economy. Entrepreneurship is directly associated with jobcreation, innovation, economic growth and development. Unfortunately, until the 1990s, the importance of entrepreneurship was undervalued and consequently downplayed in Africa[5]. However, since then, the study of entrepreneurship and indigenous private enterprise has become a significant component of research on economic development in Africa [6, 7]. Today, entrepreneurship is viewed as an essential component of economic development in the small-scale agriculture sector where local value-addition to agricultural commodities is viewed as a way for rural communities to capture a larger share of the value chain, provide nutritious, culturally-appropriate substitutes for highly processed food imports and to create job opportunities for poorly educated women. The relatively low start-up cost associated with some food processing operations makes this form of agro-entrepreneurship a realistic option for reducing the seasonal loss of perishable, but high-value, fruits and vegetables.

The discussion in this paper will focus on three key aspects of entrepreneurship cooperative business structures, market linkages and the importance of leveraging indigenous knowledge in fostering self-determined development. Cooperatives are extremely popular business structures in East Africa. In an effort to remain profitable, farmers join cooperatives, or informal groups, to gain the benefits of scale including risk mitigation, increased market leverage and access to financial resources for capital investment that can be used to purchase processing equipment, acquire storage space and/or perform other value addition function [8].

Cooperatives can also address the problem of moving perishable or shelf-stable food products quickly and cost-efficiently from rural processing facilities to urban markets or institutional customers. In highly gendered African societies, women's cooperatives specializing in value-addition to agricultural commodities find it 
relatively easy to establish credibility with customers. Having established business relationships built on trust between entrepreneurs and their customers, women's cooperatives may be able to avoid financial exploitation by middle-men or cashstrapped store owners who would prefer to delay payment until the food product has been sold. Building trusting relationships also encourages verbal exchanges that may lead to product-line extensions that appeal to new customers.

Indigenous knowledge is about the ways of knowing, seeing, and thinking that are passed down from generation to generation, and which reflect thousands of years of experimentation and innovation in all aspects of life. This knowledge is gradually being re-evaluated and considered as an inspiring source of strategies for sustainable development [9]. The knowledge has immense value for the culture in which it develops and also for entrepreneurs and problem-solvers seeking technologically and culturally appropriate solutions to community problems across the world [10]. Such knowledge is only shared among trusted family, friends and community members and Africans are especially skeptical of sharing it with individuals considered to be outsiders.

\section{Cellphones}

Cell phones have transformed the African continent. Access to cell phones in subSaharan Africa has increased dramatically over the past decade.Merely 25\% of the population has access to electricity, only $29 \%$ of the roads are paved and there are less than three landline phones per 100 people $[11,12]$. At the same time, however, there are 30 mobile phones per 100 peoplein sub-Saharan Africa, and 60 percent of the population has mobile phone access [11]. In some countries, like Tanzania, 97\% of the people have access to a cell phone, profoundly impacting people's lives and livelihoods [13]. Cell phones connect individuals to other individuals, to information, to markets, and to serviceswhile transcending male-female, urban-rural and rich-poor divides. The cell phone has gone from being a rare, expensive item used by the business elite to a pervasive, low-cost personal item that has become the world's leading telecommunications technology -with a profound impact on the social connectedness of users. An emerging body of research shows that the reduction in communication costs associated with mobile phones has tangible economic benefits in the informal economy in specific circumstances and countries $[14,15]$.

\section{Trust}

The role of trust and social capital in economic activityhas been widely researched and discussedin development discourse since the 1990s [16, 17, 18]. Lyon clarifies the concepts of trust, norms, networks and social capital and documents the mechanisms that lead to the creation of trust among farmers, traders and agricultural input suppliers [19]. Economic transactions require interaction and a level of security thatcan be based on legal measures, trust or coercion. Rural producers and traders have limited access to either legal help orlaw enforcement and hence rely largely on trust. In such situations, trust becomesthe cornerstone for the development of a thriving private sector based on microenterprises. 
The issue of trust does not arise in a perfectly competitive market place because transactions between agents are not affected by interpersonal behavioral traits and they do not have the opportunity for dishonest behavior [20, 21]. However, strong theoretical and empirical evidence suggests that price dispersion in African markets is pervasive and persistent. Personal and business relationships are based very strongly on trust and respect. The existenceof trust could promotethe growth of an individual's business network which could, in turn, enable and facilitate greater economic activity. Trust assumes a very important role in developing communities where there is a significant overlap between people's social and economic networks.A dynamic interdependence exists between social and economic capital. Social capital arises from the existence of trust in a society which, in turn, encourages cooperation in the generation of economic capital.

\section{Trust, Social Networks, Cell phones and Entrepreneurship}

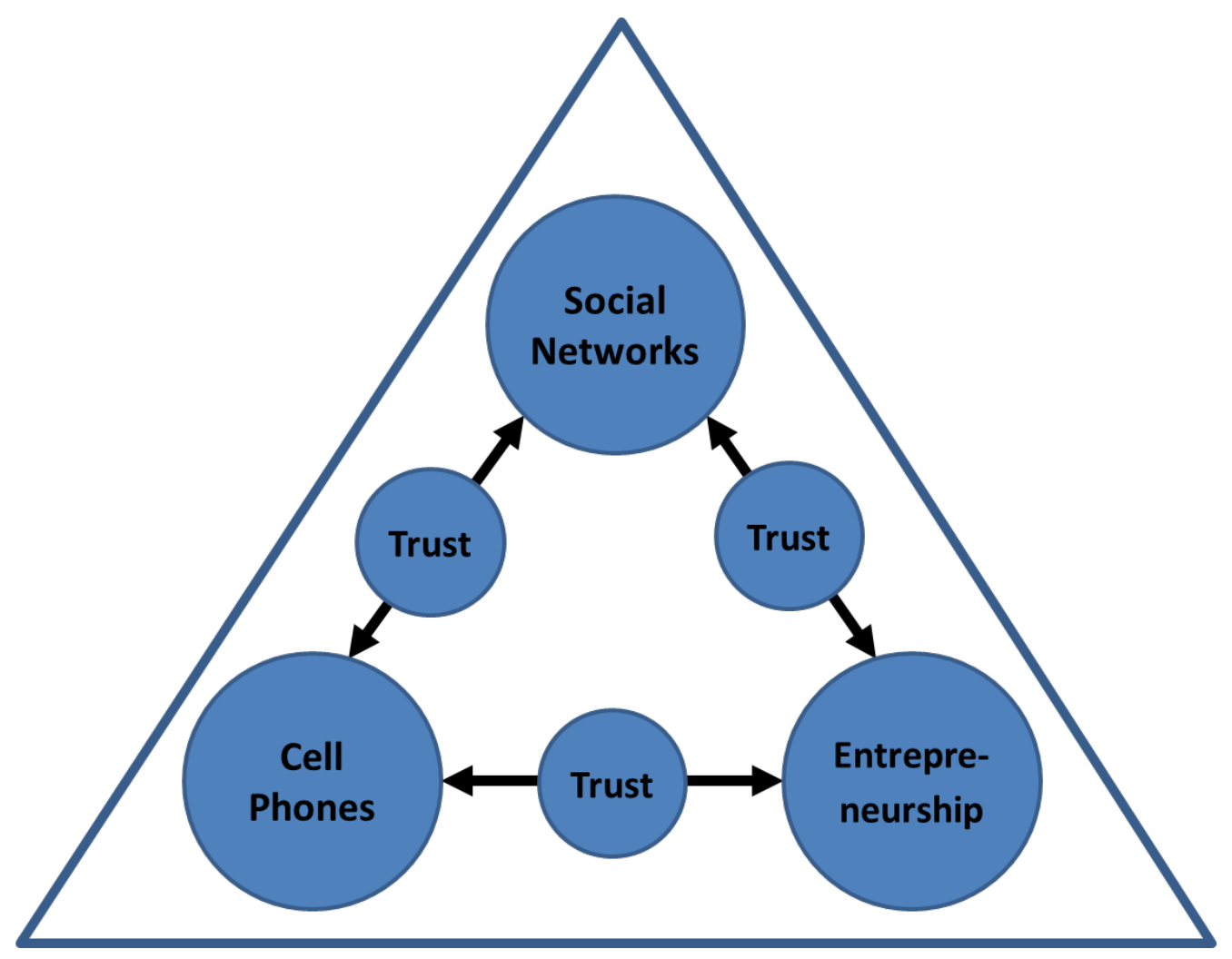

Figure 1: Social Networks, Cell phones and Entrepreneurship: the importance of Trust

The widespread adoption of cell phones has radically impacted the social connectedness of individuals and deeply affected their social networks and livelihoods. It is essential to revisit the operationalization of the concepts of trust, and social networks, and their relationship with social capital in light of the advent of cell phones. Our model(Figure 1) suggests that the most compelling opportunities for sustainable value creation and self-determined development in Africa exist at the 
intersection of cell phones, social networks and entrepreneurship, with the necessary condition that trust, the glue that holds them together, is present. The connections between the three vertices -entrepreneurship, social networks and cell phones have been illustrated and the crucial role that trust plays within these elements is discussed. The presence of trust enables and facilitates a range of opportunities that leverage social networks and cell phones in creating value for agricultural entrepreneurs. The "sweet spot" suggests a situation in whichtrust exists among partners who share a common belief that they can depend on each other in pursuit of a common purpose. Trust-based networking relationships are an important source of sustainable competitive advantage. Building trust organically and rapidly offers many opportunities for improving the livelihoods of agricultural entrepreneurs, but it remains to be seen whether the youth who, demographically, constitute a majority of the population in most African nations, will be able to create successful trust-based entrepreneurial initiatives to prevent African agriculture from slipping into the control of foreign agribusinesses.

\section{Entrepreneurship and Social Networks}

Entrepreneurs require information, capital, skills, and labor to initiatebusiness activities. Entrepreneurs possess some of these resources but they typically complement their personal resources by accessing social contacts [22, 23]. The contacts that lead to successful business outcomes are critical components of their entrepreneurial networks and serve as their social capital [24]. People draw on different social networks for different tasks. They use weak ties to access information they would not get from their close ties [25] and use family and other strong ties for obtainingeconomic resources or social support [26]. Entrepreneurs enlarge their networks to get crucial information and other valued resources from/or through knowledgeable others (their "who you know" network). Entrepreneurs also position themselves within a social network to shorten the path to knowledgeable others to get what they need [24]. Entrepreneurial networks help to establish trust and stimulate business activity [6]. Business networks have specifically been created to foster trust among members within a country or region and between members in different countries and regions. McDade and Spring cite a member of one such business network who asserts that the main asset of the network is 'the ability to pick up the phone and get the information you want from a network member; and that is forever, it does not go away'[6]. The emergence and popularity of social networks for entrepreneurs like Startup Nation, LinkedIn, Entrepreneur Connect, and Partner Up in the western world bear testimony to the importance of networks for entrepreneurs. In East Africa, entrepreneurial networks like the iHUB in Nairobi are rapidly developing to provide network support to aspiring entrepreneurs.

In the past, one of the major limitations of cooperative structures - for agriculture, finance, or other activities, has been the lack of transparency in governance and resource distribution among members [27, 28].The role cooperatives can play in improving the access of small-scale producers to consumers, as well as to supply and value networks is an important topic for research in developing regions and particularly in Africa [29]. An understanding of social networks among women shareholders and these shareholders' connections to individuals, organizations and 
agencies external to their cooperatives is important to entities working in the area of community economic development.Such awareness can result in improved efficiency in the functioning of cooperatives during the early, and very vulnerable, stage of their development[30]. Social networks also play an important role in micro-businesses. The phenomenal success of microfinance has established the importance of social networks and peer pressure inkeeping borrowers honest and hard-working. In Northern Tanzania, microfinance through SACCOS (Savings and Credit Co-operative Societies) has generated millions of shillings and is proving to be an important strategy for lifting women out of poverty. In cooperative business structures, including SACCOS, trust and transparency are pivotal to the formation, sustainability and scale-up of the organizations.

A study of macadamia nut farmers in Central Kenya and their supply chains found that existing social networks in the business were a significant barrier to entry by new farmers and agents [31]. There was a multi-level supply chain - from farmers to bike boys to brokers to agents to exporters with information asymmetries existing throughout the network. Each linkin the chain was powerless to negotiate with the next link because there was no way to tap into their networks. Higher levels of the supply chain were much better networked than lower levels. The agents and their horizontal networks enjoyed multi-stranded relationships and elaborate mechanisms to build trust and sustain their networks like participation in merry-go-rounds (Rotating Savings and Credit Accounts, or ROSCAs). These relationships further facilitated collusion on prices and the farmers had no choice but to sell at the price dictated by the brokers [31]. This case-study illustrates how the trust that connects entrepreneurs within social networks can benefit those inside the network while disadvantaging those who lack these social ties.

\section{Entrepreneurship and Cell phones}

The living standard for people at the bottom of the economic pyramid is determined largely by how much profit they realize on their outputs from agriculture, forestry or fishery activities. Dispersed markets and poor communications and transportation infrastructure lead to significant market inefficiencies and prohibit the various players from optimizing their profits. Market information is essential for informed decision making - for producers, intermediaries and even for third parties and consumers. In aclassic study conducted in Kerala in southern India, it was demonstrated that access to market information (through cell phones in this case) could improve the economic performance of small producers[14]. Information and Communication Technologies (ICTs) may help poorly functioning markets work better and thereby increase producer incomes and/or lower consumer prices. It has become increasingly common to find farmers, fishers, and other producers throughout the developing world using mobile phones, text messaging, and employing the internet for marketing their products.

Cell phone-based systems like Cellbazaar, Drumnet and DigitalICS have been developed to connect farmers, intermediaries and consumers and provide timely information about market prices and access to the latest agricultural practices[32]. In Kenya, KACE (Kenya Agricultural Commodity Exchange, Ltd.) provides a market 
information system and marketplace, with access through information centers, SMS and voice recordings via a toll-free number. Early results show significant use of the system to match local supply and demand, to learn current market prices and to provide leverage for agricultural producers with brokers and traders [33]. Trust plays a critical role in the diffusion of innovation because people prefer taking economic riskswhen dealing with trusted partners. In the agricultural sector, several studies have shown that farmers prefer receiving information from people they know and trust and who are familiar with the local farming conditions [34, 35]. Small farmers generally learn about best practices and exchange knowledge only with peers in their immediate social networks. With higher literacy levels and better access, they might be able to exchange information within extended social networks and consequently increase their profits[36].

A basic law of economics, called the law of one price, says that the price of a product should not differ between any two markets by more than the transport cost between them. This law assumes that agents have the necessary price information to engage in optimal trade. However, strong theoretical and empirical evidence suggests that price dispersion is pervasive and persistent. Much, and in some markets, most, of the observed dispersion stems from information costs - consumers' costs of acquiring information about vendors, and/or vendors costs of transmitting information to consumers [37]. Cell phones provide an unprecedented medium to democratize information-sharing and the community-building process, and bring knowledge from local residentsinto the mainstream. Peer-to-peer information sharing networks can be extremely powerful and beneficial to entrepreneurs. These networks can be successful only if there is a user-regulated mechanism that assigns a measure of trust to the information and the individual who contributes it.

\section{Cell phones and Social Networks}

Cell phones help to easily maintain long distance business connections as well as social ties and to decrease dependency on local face-to-face relationships. Cell phones have a profound impact on the social connectedness of users. Users develop numerous contacts at greater distances from their home or place of business. As the category of casual (weak-tie) relationships emerges, this category comes to encompass an everlarger share of the total number of an individual's social contacts with others and more and more weak-tie relationships come to exist in a person's life. When this shift in friendship categories occurs, an individual becomes less dependent on fraternal relationships at the family, village, clan or tribal level. The new weak social ties may be economically beneficial because weak social ties often lead to new resources and larger networks. Though the mobile phone does not uniquely cause these social network transformations, it further enables and accelerates them [38].

Facilitating the creation of trusting relationships is an essential step after people have connected digitally. However, establishing trusting relationships between strangers is difficult because, while cell phones make long-distance communication easier, the assessmentof someone's trustworthinessis still based on the informal, unwritten moral laws of families, clans, ethnic associations,marketplaces, churches, and the street[39]. A history of previous positive experiences is considered the strongest trust signal, and 


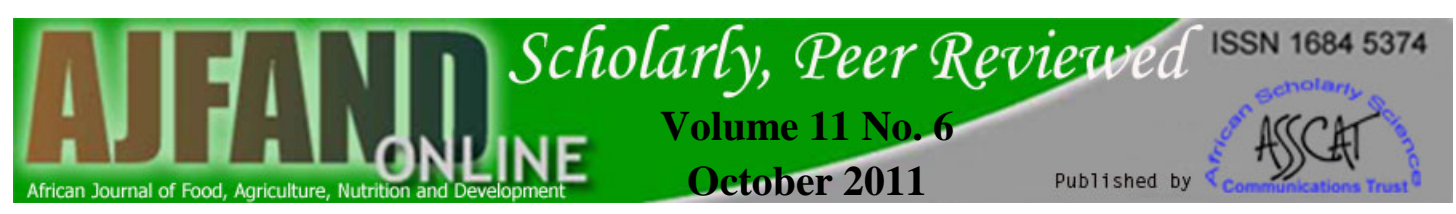

suggests higher certainty and less risk in conducting business [40]. Cell phone-based social networking applications can develop a system of digital trust within a trusted community. While digital trust can never substitute for interpersonal contact, it is a building block that can allow more people to exchange reliable information and conduct improved business negotiations by leveraging their digital reputation to foster a new means of accountability.

Attracted by the 4.7 billion cell phone subscribers around the world, more than thirty startup companies are developing applications to provide social networking on cell phones [41]. Cell phones provide a major advantage over computers - the ability to know the user's current location by embedded Global Positioning System (GPS) technology. However, GPS-enabled cell phones are not yet common in Africa. Technical experts at African ICT companies suggest that Facebook is creating demand for their services. Current clients want faster internet connectivity to download all the images and video sent their way via Facebook, and more technology (cameras, video and image-editing software) to create content for their Facebook pages. According to its website, Facebook has over 300,000 users in Kenya, is the most popular site in South Africa, and is growing by 20,000 new users per month in Nigeria and Ghana. Facebook, and other similar social networks will undoubtedly connect many people and accelerate the formation of weak-tie relationships. Social networking via cell phone will facilitate the formation of trust networks and will ultimately determine the utility of such digital networks in fostering entrepreneurship and transforming the users' livelihoods.

\section{Nutribusiness Co-operatives: The Kenya Experience}

The Pennsylvania State University, a large research institution in the United States, led amulti-institutional,USAID-funded development project in Kenya from 1992 to 1999[30, 42]. The project addressed UN Millennium Development Goals [43]by establishing a nutribusiness cooperative in Central Kenya with the social goal of improving, respectively, the livelihoods and the nutritional status of rural women and children. The nutribusiness cooperative produced a nutritious, shelf-stable porridge mix made from locally-grown agricultural commodities that included maize, bananas, dried beans, carrots, pumpkin, pumpkin leaves and amaranthus leaves. The product was created by the members of the cooperative with technical support from the participating universities. It was registered with the Kenya Bureau of Standards and is currently sold in several supermarkets in the Nairobi area.

On reflectionit seems likely that the nutribusiness operation was constrained, in part, by issues of trust which could have been overcome if the social networks of the shareholders had been addressed. The $\sim 500$ initial members of the cooperative resided in three separate sub-locations where they were members of close-knit women's groups that were often comprised of members of the same family. Although women from each of the sub-locations were involved in the various project training activities, these educational activities were not structured with the goal of building trust and it was assumed by the cooperative members that those who attended the trainings would usethe information gained to the advantage of their relatives and friends. The 
cooperative's elected officers (Chairlady, Secretary and Treasurer) represented the three geographic sub-locations, but, as a group, these leaders were not well known or fully trusted by the total membership. Only the chairlady, who owned an established business in the district center, had ties to government ministries and nongovernmental organizations. These connections were essential in obtaining infrastructure required by the cooperative. However, it was only when a marketing entrepreneur with previous ties to the chairlady took on the task of building relationships with supermarkets that orders for the cooperative's product began to be received and needed repairs to its equipment were made.

When the nutribusiness cooperative was being established in the early 90s, there was no piped water or electricity available in the area and cell phones were unheard of. At the present time, cell phone-based applications could be effectively used by the cooperative to access market information and maintain, manage and expand their social networks. This use of technology could result in a higher social and economic profit for the nutribusiness and improve its potential for scalability.A study of member commitment to, and satisfaction with, the nutribusiness cooperative was conducted in 2009. The study found that although general members have received few financial returns from the cooperative,and have a lower level of satisfaction with itthan do the cooperative'sleaders, they never-the-less maintain a strong psychological commitment to the collaborative entrepreneurial initiative[44]. This commitment suggests that if a more appropriate organizational structure is put in place and communication linkages are maintained through the use of cell phones, the level of trust between leaders and members could be strengthened, possibly enabling this rural women's cooperative to achieve its economic and social objectives.

Research clearly indicates that social relationships have an important place in market exchange [4, 45, 46] but relatively little is known about what role social networks might play in women's microeconomic enterprises. The failure of the Kenyan cooperativeto developand utilize itscollective network knowledge may have accounted for some of the challenges itexperienced. "Network knowledge" is social capital that a women's nutribusiness cooperative could be encouraged to use creatively to achieve its social and economic goals. The social networking process mightbe optimized by strengthening weak social ties that could be particularly beneficial to the success of a nutribusiness cooperative and de-emphasizing the traditionally strong social ties within subgroups of women that can inhibit transparency and democratic decision-making in a new, geographically dispersed nutribusiness organization.

\section{CONCLUSION}

In this paper the authors describe the dynamic interdependence that exists among several of the key elements required for the establishment of sustainable agricultural business ventures in Africa, namely entrepreneurship, social networks and cell phones. However, it is our hypothesis that the successful integration of these elements is unlikely to occur without the establishment of interpersonalrelationships that are built upon mutual trust. A related research paper on the "who you know" social and 
economic network knowledge systems among rural women agro-entrepreneurs in Northern Tanzania and the role cell phones play within these networks further validates our hypothesis.

Acknowledgements: This study was funded by a Level-2grant from the Social Science Research Institute at Penn State titled "How Well-Networked Are Rural Women Agro-Entrepreneurs in Northern Tanzania? A Social Network Analysis Pilot Project” 


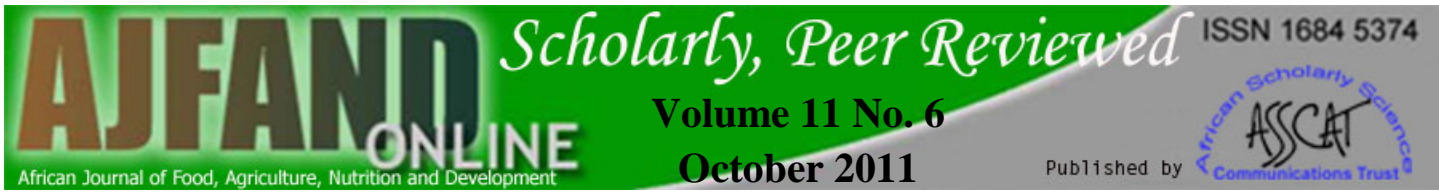

\section{REFERENCES}

1. Mehta KM, Semali L, Maretzki A, Findeis J, Kuldau G and K Willyerd "Cell phones and Social Networks: Defining new opportunities and discovering champions for entrepreneurial ventures in developing communities", NCIIA Annual Meeting, Washington DC, March 2009

2. Wasserman $\mathbf{S}$ and $\mathbf{F}$ Faust Social Network Analysis: Methods and Applications. London : Cambridge University Press, 2007.

3. Scott J Social network analysis. A handbook. London : Sage, 2000.

4. Granovetter M Getting a Job: A Study of Contacts and Careers. Chicago : University of Chicago Press, 1995.

5. Marsden K African Entrepreneurs-Pioneers of Development. 2, Small Enterprise Development, 1992, Vol. 3, pp. 15-25.

6. Spring A and B McDade African Entrepreneurship: Theory and Reality. Gainesville, FL : University of Florida Press, 1998.

7. Murinde $\mathbf{V}$ and A Woldie African Business Finance and Development Policy. New York : The Haworth Press, 2003.

8. USDA Cooperative benefits and limitations 1990. www.rurdev.usda.gov/RBS/pub/cir1sec3.pdf.

9. Fernando JL NGOs and the production of indigenous knowledge under the condition of postmodernity. 1, Annals of the American Academy of Political and Social Science, 2003, Vol. 590, pp. 54-72.

10. Mehta K, Semali L, Fleishman A and A Maretzki "Leveraging Indigenous Knowledge to foster Developmental Entrepreneurship", NCIIA Annual Conference, Alexandria, March 2011

11. International Telecommunication Union. Information Society Statistical Profiles. Geneva : International Telecommunications Union, 2009.

12. World Bank. World Development Indicators. Washington, D.C. : s.n., 2009. http://publications.worldbank.org/WDI/.

13. BBC. Mobile Phones Boom in Tanzania. [Online] 2005. http://news.bbc.co.uk/1/hi/programmes/click_online/4706437.stm.

14. Jensen $\mathbf{R}$ The digital provide: information (technology), market performance, and welfare in the South Indian fisheries sector, The quarterly journal of economics, 2007 
15. Aker JC Does Digital Divide or Provide? The Impact of Mobile Phones on Grain Markets in Niger. s.l. : BREAD Working Paper \# 177, 2008.

16. Fafchamps $\mathbf{M}$ The enforcement of commercial contracts in Ghana, 3, World Development, 1996, Vol. 24, pp. 427-448.

17. Humphrey $\mathbf{J}$ and $\mathbf{H}$ Schmitz Trust and economic development, Brighton : Institute of Development Studies, Vol. Discussion Paper 355.

18. Berry S No condition is permanent; the social dynamics of agrarian change in sub-Saharan Africa, Madison, WI : University of Wisconsin Press, 1993.

19. Lyon F Trust, networks and norms: the creation of social capital in agricultural economies in Ghana 4, World Development, Vol. 28, pp. 663681.

20. Furlong D The conceptualization of 'trust' in economic thought. Sussex, UK : Institute of Development Studies, Vol. Working Paper 35.

21. Platteau JP Behind the market stage where real societies exist, Part II, the role of moral norms. 4, Journal of Development Studies, Vol. 30, pp. 753-817.

22. Aldrich $\mathbf{H}$ and $\mathbf{C}$ Zimmer Entrepreneurship through social networks. The Art and Science of Entrepreneurship. New York : Ballinger, 1986.

23. Hansen EL Entrepreneurial network and new organization growth. Entrepreneurship: Theory \& Practice, 1995, pp. 7-19.

24. Burt RS Structural Holes: The Social Structure of Competition. Cambridge, MA : Harvard University Press, 1992.

25. Granovetter M The strength of weak ties, American Journal of Sociology, 1973, pp. 1360-1380.

26. Krackhardt D The strength of strong ties: The importance of philos in organizations. [book auth.] $\mathrm{N}$ Nohria and $\mathrm{R}$ G Eccles. Networks and Organizations: Structure, Form, and Action. Boston : Harvard University Press, 1992, pp. 216-239.

27. The Hindu. Coop bank scams: Effective governance structure crucial. 2002.

28. Mehta K Lessons from the Field: Setting up a windmill based business in rural Kenya. Dallas, TX : NCIIA, Proceedings of the NCIIA 12th Annual Meeting. 2008, pp. 169-177.

29. FAO. Is Small Really More Beautiful?: Efficiency, Innovation and Location. Rome: s.n., 2005. Agricultural Commercialization and the Small Farmer Symposium. 
30. Maretzki A Women's NutriBusiness Cooperatives in Kenya: An Integrated Strategy for Sustaining Rural Livelihoods. 6, African Journal of Food, Agriculture, Nutrition and Development, 2009, Vol. 9.

31. Garguilo S, Prindible M, Okello A and K Mehta "Labor hiring practices and produce supply chains in rural Kenya: the case for WishVast networking”, International Journal for Service Learning in Engineering: Humanitarian Engineering and Social Entrepreneurship, Vol 5, No 1, 2010

32. Parikh T, Patel N and Y Schwartzman A Survey of Information Systems Reaching Small Producers in Global Agricultural Value Chains, 2007.

33. KACE. Kenya Agricultural Commodities Exchange (KACE). [Online] 2008. http://www.kacekenya.com.

34. Kafewo DS Simli Radio: deconstructing the myth of broadcasting. Africa Media Development Initiative, 2006

35. Microsoft Research India. Digital Green. [Online] August 2008. http://www.digitalgreen.org.

36. Duflo E, Kremer $\mathbf{M}$ and $\mathbf{J}$ Ro Why don't farmers use fertilizers: Evidence from field experiments in Western Kenya. 2006.

37. Baye $\mathbf{M}$, Morgan $\mathbf{J}$ and $\mathbf{P}$ Scholten Information, Search, and Price Dispersion. [book auth.] Terry Hendershott. Handbook on Economics and Information Systems. s.l. : Elsevier, 2006.

38. Sood A The Mobile Development Report. s.l.: The Centre for Knowledge Societies, 2006.

39. Overa R Networks, Distance, and Trust: Telecommunications Development and Changing Trading Practices in Ghana.7, 2006, World Development, Vol. 34.

40. Siau K and Z Shen Building Customer Trust in Mobile Commerce. 4, 2003, Communications of the ACM, Vol. 46.

41. New York Times. Social Networking Moves to the Cell phone. [Online] 2008.

http://www.nytimes.com/2008/03/06/technology/06wireless.html?_r=1\&ref=t echnology\&oref=slogin.

42. Maretzki A Women's NutriBusiness Cooperatives in Kenya - A Prologue. 8, African Journal of Food, Agriculture, Nutrition and Development, 2009, Vol. 9. 
43. United Nations. The millennium development goals report. New York: United Nations, 2005.

44. Marete MA The Influence of Cooperative Structure on Member Commitment, Satisfaction and Success: The Murang'a Nutribusiness Cooperative in Kenya.The Pennsylvania State University, Department of Agricultural and Extension Education, 2010. Ph.D. Dissertation.

45. Coleman JS Social Capital in the Creation of Human Capital. American Journal of Sociology, 1988, pp. S95-S120.

46. Putnam R The Prosperous Community - where you live and whom you know: Social Capital and Public Life. 1993, The American Prospect, pp. 4-13. 